\title{
PENGARUH PENGGUNAAN METODE DISCOVERY TERHADAP KEMAMPUAN ANALOGI MATEMATIS SISWA SMK AL-IKHSAN PAMARICAN KABUPATEN CIAMIS JAWA BARAT
}

\author{
Oleh: \\ ${ }^{1)}$ Risqi Rahman, ${ }^{2)}$ Samsul Maarif \\ ${ }^{1,2}$ Pendidikan Matematika FKIP UHAMKA \\ ${ }^{1}$ risqirahman@yahoo.co.id
}

\begin{abstract}
ABSTRAK
Penelitian ini merupakan penelitian dengan desain factorial disign, yang bertujuan untuk mengetahui pengaruh metode discovery terhadap kemampuan analogi dan generalisasi matematis siswa SMK. Populasi penelitian ini adalah seluruh siswa SMK Al-Ikhsan Pamarican Kabupaten Ciamis Jawa Barat, dan pengambilan sampel penelitian dilakukan dengan teknik Cluster Random Sampling, yaitu dengan memilih siswa kelas X sebanyak dua kelas sebagai sampel dalam penelitian ini. Penelitian ini terdiri dari dua kelompok pembelajaran, yaitu pembelajaran dengan metode discovery dan pembelajaran dengan metode ekspositori. Kelas X.1 dijadikan sebagai kelompok eksperimen, sedangkan kelas X.2 dijadikan sebagai kelompok kontrol. Setiap kelompok terdiri dari 36 siswa yang terbagi kedalam tiga kemampuan siswa berbeda, yaitu siswa berkemampuan tinggi, siswa berkemampuan sedang dan siswa berkemampuan rendah kelasnya. Data penelitian dikumpulkan melalui tes, angket, observasi dan wawancara. Hasil penelitian ini adalah Peningkatan kemampuan analogi matematis siswa yang memperoleh pembelajaran dengan metode discovery lebih baik daripada siswa yang memperoleh metode pembelajaran dengan metode ekspositori.
\end{abstract}

Kata Kunci : pembelajaran dengan metode discovery, kemampuan analogi matematis

\begin{abstract}
This research is disign factorial design, which aims to determine the effect on the ability analogy discovery method and SMK students' mathematical generalization. The study population was all students of SMK Al - Ikhsan Pamarican Kudat District of West Java, and sampling studies conducted by cluster random sampling technique, ie by selecting the class $\mathrm{X}$ as much as two classes as the sample in this study. The study consisted of two groups of learning, ie learning by discovery and learning method with expository method. X.1 class used as the experimental group, while the X.2 class used as the control group. Each group consisted of 36 students, divided into three different student abilities, ie high ability students, students and students capable of being low-ability class. Data were collected through tests, questionnaires, observations and interviews. The results of this study are the increased capability of mathematical analogy with the learning of students who obtain discovery method is better than the students who received learning method with expository method.
\end{abstract}

Keywords : learning by discovery method, the ability of mathematical analogy 


\section{PENDAHULUAN}

Dalam menjalani abad ke 21, kita bangsa Indonesia harus mempersiapkan sumber daya manusia (SDM) yang benar-benar unggul dan dapat diandalkan untuk menghadapi persaingan bebas di segala bidang kehidupan yang kian ketat sebagai dampak dari globalisasi dunia. Dampak globalisasi dunia tidak hanya kita rasakan pada sendi-sendi perekonomian, pertahanan-keamanan, politik dan sosial budaya semata, namun juga pada sendi-sendi pendidikan pada umumnya. Bila kualitas pendidikan dalam negeri terjamin, maka tentu pendidikan kita minimal akan menjadi tuan di negaranya sendiri. Oleh karena itu merupakan suatu hal yang logis bila kita harus lebih memperhatikan kualitas pendidikan.

Pendidikan merupakan ujung tombak dalam mempersiapkan SDM yang handal, karena pendidikan diyakini akan dapat mendorong memaksimalkan potensi siswa sebagai calon SDM yang handal untuk dapat bersikap kritis, logis dan inovatif dalam menghadapi dan menyelesaikan setiap permasalahan yang dihadapinya. Hal tersebut senada dengan pendapat Sumarmo (2004:1) yang menyatakan bahwa pendidikan matematika sebagai proses yang aktif, dinamik, dan generatif melalui kegiatan matematika (doing math) memberikan sumbangan yang penting kepada siswa dalam pengembangan nalar, berfikir logis, sistematik, ktitis dan cermat, serta bersikap obyektif dan terbuka dalam menghadapi berbagai permasalahan. Oleh karena itu tidaklah mengherankan bila matematika merupakan mata pelajaran yang terdapat dalam setiap jenjang pendidikan, baik pendidikan di lembaga formal maupun di lembaga non formal, bahkan di lembaga latihan kerja serta bidang lain yang berkaitan dengan tujuan peningkatan kualitas SDM sekalipun.

Tetapi faktanya, Hasil Penelitian The Third International Mathematics and Science Study (TIMSS) yang dilakukan terhadap siswa SMP kelas dua di Indonesia terhadap nilai rata-rata matematika yang dicapai hanya 397 jauh di bawah rata-rata internasional TIMSS yang mencapai 500 (TIMSS, 2008). Nilai yang dicapai siswasiswa Indonesia ternyata juga lebih rendah apabila dibandingkan dengan beberapa negara lain di kawasan Asia seperti Taiwan (dengan rata-rata nilai 598), Korea Selatan (597), Singapura (593), jepang (570) bahkan Malaysia (474). Sedangkan laporan PISA 2006, Indonesia menempati rangking 52 dari 57 negara. Sementara hasil nilai matematika pada Ujian Nasional, pada semua tingkat dan jenjang pendidikan selalu terpaku pada angka yang rendah.

Metode yang kerap guru gunakan adalah metode ekspositori dengan menerangkan materi dan selanjutnya memberi contoh soal. Hal tersebut disebabkan oleh beberapa kemungkinan yaitu: 1) Sekolah sudah memiliki alat peraga tetapi belum memanfaatkannya secara optimal. 2) Sekolah sama sekali belum memiliki alat peraga. 3) Sekolah telah memiliki alat peraga namun belum memadai baik tempat, kualitas maupun kuantitasnya (Asyhadi, 2005). 
Rendahnya kemampuan penalaran matematis siswa berdampak pada rendahnya prestasi belajar matematikanya. Hal ini sesuai dengan temuan Wahyudin (Herdian, 2010:1) dalam penelitiannya yang menemukan bahwa salah satu kecenderungan yang menyebabkan sejumlah siswa gagal menguasai dengan baik pokok-pokok bahasan dalam matematika akibat siswa kurang menggunakan nalar yang logis dalam menyelesaikan soal atau persoalan matematika yang diberikan. Hasil penelitian Rif'at (Suzana, 2003: 2) juga menunjukkan kelemahan kemampuan matematika siswa dilihat dari kinerja dalam bernalar. Misalnya, kesalahan dalam penyelesaian soal matematika disebabkan karena kesalahan menggunakan logika deduktif.

Penalaran adalah dua hal yang tidak dapat dipisahkan karena matematika dipahami melalui penalaran, sedangkan penalaran dipahami dan dilatihkan melalui belajar matematika. Ini diperkuat dengan hasil penelitian yang dilakukan oleh oleh Prowsri dan Jearakul (Priatna, 2003: 4) bahwa pada siswa sekolah menengah Thailand terdapat keterkaitan yang signifikan antara kemampuan penalaran dengan hasil belajar matematika mereka. Hal ini menunjukkan bahwa kemampuan penalaran berperan penting dalam keberhasilan siswa. Siswa yang memiliki kemampuan penalaran yang baik diharapkan mempunyai prestasi belajar matematika yang baik pula.

Sastrosudirjo mengungkapkan bahwa analogi kemampuan melihat hubunganhubungan, tidak hanya hubungan benda-benda tetapi juga hubungan antara ide-ide, dan kemudian mempergunakan hubungan itu untuk memperoleh benda-benda atau ide-ide lain. Sedangkan menurut Soekadijo (1999: 139) analogi adalah berbicara tentang dua hal yang berlainan, yang satu bukan yang lain, tetapi dua hal yang berbeda itu dibandingkan satu dengan yang lain. Dalam analogi yang dicari adalah keserupaan dari dua hal yang berbeda, dan menarik kesimpulan atas dasar keserupaan itu. Dengan demikian analogi dapat dimanfaatkan sebagai penjelas atau sebagai dasar penalaran.

Dengan kasus-kasus analogi siswa dilatih untuk melihat sejauh mana mereka memahami konsep dan melihat struktur mikroskopis konsep dengan menelaah keterkatan antar konsep dengan kasus analogi, serta membuka pikiran siswa tentang aplikasi atau manfaat dari mempelajari konsep tersebut. sehingga siswa dapat mengontrol atau memonitor pemahaman mereka mengenai sesuatu yang sedang dipelajari dan menyadari akan kelebihan dan keterbatasannya dalam belajar sehingga ia akan mencari solusi yang tepat untuk menyempurnakan kelemahannya dalam belajar.

Untuk mengembangkan kemampuan analogi matematis diperlukan sebuah metode pembelajaran yang mempunyai karakteristik membangun katagori, menentukan masalah dan menciptakan lingkungan yang mendukung (Pott, 1994). Metode pembelajaran yang mempunyai karakteristik tersebut diantaranya Discovery 
Learning. Hal ini didasarkan pada proses pembelajaran penemuan yang digambarkan Veermans (Lakkala, Ilomakki, dan Veermans, 2003) yaitu orientasi, menyusun hipotesis, menguji hipotesis, membuat kesimpulan dan mengevaluasi (mengontrol).

Ruseffendi (1991: 329) mengemukakan bahwa metode discovery adalah metode mengajar yang diatur sedemikian rupa sehingga anak memperoleh pengetahuan yang sebelumnya belum diketahuinya itu tidak melalui pemberitahuan, dimana sebagian atau seluruh pengetahuan ditemukan sendiri dengan bantuan guru. Sejalan dengan Ruseffendi, Sund (Suriadi, 2006: 5) mengungkapkan bahwa penemuan ialah proses mental dimana siswa mampu mengasimilasikan suatu konsep atau prinsip. Proses mental yang dimaksud antara lain: mengamati, mencerna, mengerti, menggolong-golongkan, membuat dugaan, menjelaskan, mengukur, membuat kesimpulan dan sebagainya. Diharapkan, jika siswa secara aktif terlibat didalam menemukan suatu prinsip dasar sendiri, Ia akan memahami konsep lebih baik, ingat lama dan akan mampu menggunakannya kedalam konteks yang lain.

Dari uraian di atas maka melalui penelitian ini akan diungkap " pengaruh penggunaan metode discovery terhadapkemampuan analogi matematis siswa SMK Al-Ikhsan Pamarican Kabupaten Ciamis Jawa Barat”.

\section{KAJIAN PUSTAKA}

\section{Matematika}

Matematika berasal dari bahasa Yunani "mathematike" yang berarti "relating to learning”. Kata mathematike mempunyai akar kata mathema yang artinya pengetahuan atau ilmu. Kata mathematike serupa dengan mathanein artinya belajr atau bergikir. Menurut Elea Tinggih dikutip oleh Erman Suherman, secar etimologis "matematika berarti ilmu yang diperoleh dengan bernalar" (Suherman , 1995:119). Hal ini menekankan bahwa dalam matematika lebih diutamakan aktivitas dalam dunia rasio (penalaran).

Pada tahap awal matematika terbentuk dari pengalaman manusia dengan dunianya secara empiris. Kemudian matematika tumbuh dan berkembang melalui proses berfikir yang dilakukan oleh manusia yang disebut logika. Dengan logika objek matematika yang abstrak dapat dijelajahi. Objek matematika tersebut dibedakan oleh E. T. Ruseffendi menjadi dua, yakni :

Objek langsung, meliputi: Fakta adalah angka atau lambang bilangan, keterampilan adalah kemampuan memberikan jawaban yang benar dan cepat, konsep adalah ide ekstrak yang memungkinkan kita mengelompokkan benda-benda (objek) ke dalam contoh, aturan adalah objek yang paling abstrak (2) Objek tidak langsung, meliputi: 
Kemampuan menyelidiki, kemampuan memecahkan masalah, kemampuan belajar dan bekerja mandiri, bersikap positif terhadap matematika ( Ruseffendi : 165).

Dilihat dari objek penelaahannya, matematika lebih menitikberatkan kepada hubungan, pola, bentuk dan struktur yang diatur secara logis. Oleh sebab itu matematika memiliki empat cakupan yang luas yakni aritmatika, aljabar, geometri dan analisis. Hubungan-hubungan yang ada dalam matematika berkaitan erat dengan kehidupan sehari-hari. Misalnya tentang kesamaan, lebih kecil dan lebih besar. Hubungan-hubungan tersebut berupa dalil, sifat, atau teori-teori yang kebenarannya harus dibuktikan secara deduktif. Dari hubungan-hubungan yang telah diintegrasikan ke dalam kehidupan sehari-hari dapat dibentuk suatu pola yang kemudian dianalisis sehingga pola-pola tersebut dapat dikenal bila sewaktu-waktu muncul. Pola-pola yang telah memilki keteraturan menjadi dasar untuk menelaah struktur yang ada dalam matematika. Hal ini menekankan bahwa dalam matematika lebih diutamakan hubungan-hubungan antar struktur itu dan aturan-aturan yang mengatur langkah-langkah operasinya. Oleh sebab itu matematika merupakan ilmu yang tentang struktur yang terorganisasi dengan rapi.

\section{Penalaran Induktif}

Untuk memperoleh pengetahuan ilmiah dapat digunakan dua jenis penalaran, yaitu penalaran deduktif dan penalaran induktif. Penalaran induktif merupakan prosedur yang berpangkal dari peristiwa khusus sebagai hasil pengamatan empirik dan berakhir pada suatu kesimpulan atau pengetahuan baru yang bersifat umum. sebagai contoh: bilangan $4=3 \times 1+1,9=3.3,16=3 \times 5+1,25=3 \times 8+1,36=3 \times 12$, dan seterusnya. Dari kejadian atau fakta-fakta tersebut kita bisa menyimpulkan bahwa setiap bilangan kuadrat sempurna $a^{2}$ akan memenuhi bentuk $3 k$ atau $3 k+1$ untuk semua $k$ anggota bilangan bulat. Dari contoh tersebut dapat dilihat dari fakta-fakta dapat kita tarik sebuah kesimpulan untuk ditentukan keumumannya.

Sumarmo (1987: 39-42) mengatakan bahwa penalaran induktif terdiri dari terdiri dari tiga jenis yaitu: generalisasi, analogi dan hubungan kausal (sebab akibat). Penalaran induktif juga melibatkan persepsi tentang keteraturan. Keteraturan itu terlihat misalnya dalam menarik kesimpulan dari kasus-kasus yang bersifat khusus kemudian menemukan pola/ aturan yang melandasinya atau dalam mendapatkan kesamaan/ keserupaan dari contoh-contoh yang berbeda. Dalam matematika, menarik kesimpulan dari kasus-kasus yang bersifat khusus dan mendapatkan kesamaan/ keserupaan dari contoh-contoh yang berbeda dapat menjadi dasar dalam rangka pembentukan konsep. Proses penalaran dengan mengaitkan konsep yang serupa dinamakan analogi matematis, sedangkan menarik kesimpulan dari kasus yang bersifat khusus dinamakan generalisasi matematis.

Penalaran induktif dibagi menjadi 3 bagian yaitu generalisasi, analogi dan sebabakibat. Menurut Sumarmo (1987, h.39): 
a. Generalisasi merupakan proses penalaran yang berdasarkan pada pemeriksaan hal-hal secukupnya kemudian memperoleh kesimpulan untuk semuanya atau sebagian besar hal-hal tadi. Untuk matematika tingkat lanjutan, untuk memeriksa kebenaran hasil yang diperoleh dalam penyimpulan, maka dilakukan pemeriksaan dengan induksi matematika. Hal ini dimaksudkan untuk membuktikan apakah penyimpulan yang diperoleh berlaku untuk semua.

Sebagai contoh:

Ani siswa SMA berseragam putih abu-abu

Edi siswa SMA berseragam putih abu-abu

Badu siswa SMA berseragam putih abu-abu

Yanti siswa SMA berseragam putih abu-abu

Jadi kesimpulannya mungkin semua siswa SMA berseragam putih abu-abu.

b. Analogi merupakan penalaran dari satu hal tertentu kepada satu hal lain yang serupa kemudian menyimpulkan apa yang benar untuk satu hal juga akan benar untuk hal lain. Gambar di bawah ini adalah contoh analogi:

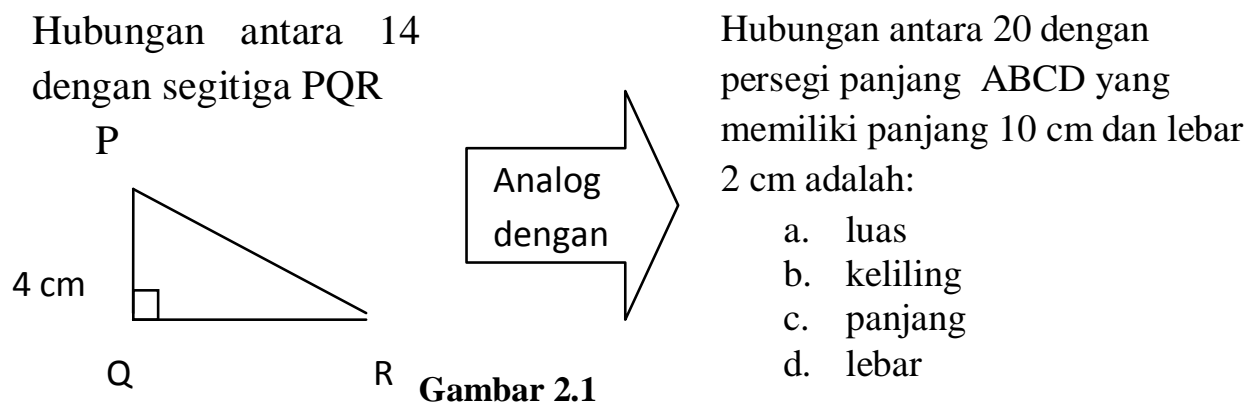

Jawaban untuk pertanyaan di atas adalah hubungan antara 14 dengan segitiga PQR analog dengan hubungan antara 20 dengan luas segi empat

ABCD. Sebab 14 merupakan luas segitiga PQR dan 20 merupakan luas segi empat ABCD.

c. Sebab-akibat, pengertian sebab-akibat hampir sama dengan penalaran generalisasi induktif hanya saja pada pengambilan kesimpulannya berdasarkan pada karakteristik objek yang memungkinkan terjadinya keserupaan atau ketidakserupaan objek.

Contoh sebab-akibat:

Louis Pasteur seorang ilmuwan meneliti beberapa macam penyakit yang disebabkan oleh kuman, baru-baru ini terdapat penemuan yang sangat penting yakni penyakit kanker paru-paru yang disebabkan oleh rokok. 
Adapun penalaran induktif yang akan dikaji dalam penelitian ini adalah penalaran analogi dan generalisasi matematis.

\section{Kemampuan Analogi Matematis}

Analogi adalah membandingkan dua hal yang berlainan berdasarkan keserupaannya. Selain mencari keserupaan di antara dua hal yang berlainan, analogi juga menarik kesimpulan atas dasar keserupaan tersebut. Dengan demikian analogi digunakan sebagai penjelasan atau sebagai dasar penalaran.

Menurut Mundiri (2000: 137), ada dua macam analogi, yaitu analogi induktif dan analogi deklaratif atau analogi penjelas. Analogi induktif adalah analogi yang disusun berdasarkan persamaan prinsipil yang berbeda pada dua fenomena, selanjutnya ditarik kesimpulan bahwa apa yang terdapat pada fenomena pertama terdapat pula pada fenomena kedua. Sedangkan analogi deklaratif atau analogi penjelas merupakan metode untuk menjelaskan sesuatu yang belum dikenal atau masih samar, dengan menggunakan hal yang sudah dikenal.

Suherman (2001: 134) menjelaskan bahwa matematika di sekolah berperan untuk: (1) untuk mempersiapkan anak didik agar mampu menghadapi perubahan-perubahan keadaan di dalam kehidupan di dunia yang senantiasa berubah, melalui latihan bertindak atas dasar pemikiran logis dan rasional, kritis dan cermat, objektif, efektif, dan diperhitungkan secara analitis sintetis, (2) untuk mempersiapkan anak didik agar menggunakan matematika secara fungsional dalam kehidupan sehari-hari dan di dalam mengahadapi ilmu pengetahuan lain.

Lawson (Suriadi, 2006) mengungkapkan keuntungan analogi dalam pengajaran antara lain:

a. dapat memudahkan siswa dalam memperoleh pengetahuan baru dengan cara mengaitkan atau membandingkan pengetahuan analogi yang dimiliki siswa

b. pengaitan tersebut akan membantu mengintegrasikan struktur-struktur pengetahuan yang terpisah agar terorganisasi menjadi struktur kognitif yang lebih utuh. Dengan organisasi yang lebih utuh akan mempermudah proses pengungkapan kembali pengetahuan baru

c. dapat dimanfatkan dalam menanggulangi salah konsep.

d. Menurut Sumarmo (1987) memberikan gambaran indikator untuk mengukur kemampuan penalaran analogi, yaitu: a) Siswa dapat mengamati pola (dari sebuah gambar atau sebuah bilangan), b) Siswa dapat menentukan hubungan antara pola gambar atau bilangan tersebut, c) Siswa dapat mengestimasi atau memperkirakan aturan yang membentuk pola tesebut.

\section{Metode Pembelajaran Matematika}

Banyak ahli mendefinisikan pengertian tentang metode pembelajaran, tapi pada intinya metode mengajar merupakan suatu cara menyampaikan materi/bahan ajar 
dari seorang pendidik terhadap peserta didiknya sehingga materi yang diberikan dapat terserap sesuai dengan yang diharapkan. Menurut Muhibbin (1995:22) metode secara harfiah berarti cara, dan dalam pemakaian yang umum, metode diartikan sebagai cara melakukan suatu kegiatan atau cara melakukan pekerjaan dengan menggunakan fakta dan konsep-konsep secara sistematis. Senada dengan itu, Ruseffendi (1991:281) berpendapat metode mengajar adalah cara mengajar atau cara menyampaikan materi pelajaran kepada siswa untuk setiap pelajaran atau bidang studi. Macam-macam metode mengajar adalah ceramah, ekspositori, tanya jawab, demonstrasi, kegiatan lapangan, diskusi, dan lain-lain.

Belajar mengajar dapat dikatakan berhasil, apabila tujuan yang telah ditetapkan dapat tercapai dengan baik. Demikian pula dengan kegiatan belajar mengajar matematika akan berhasil, jika tujuan dari pengajaran matematikanya tercapai dengan baik pula. Dalam meraih keberhasilan tersebut guru sangat berperan, terutama memilih metode mana yang sesuai dengan materi pengajaran yang akan disampaikan, sehingga dalam proses pembelajaran siswa dapat belajar aktif, dengan belajar aktif siswa akan tahan lebih lama menyimpan materi pelajaran yang sudah diberikan guru, pengetahuan lebih luas, dan konsep lebih tertanam bila dibandingkan dengan cara belajar yang terfokus pada guru semata. Selanjutnya, melalui cara belajar yang aktif dapat menumbuhkan sikap kreatif siswa, sehingga ia dapat mengaplikasikan pelajaran yang diterima di sekolah dengan keadaan kondisi dikehidupan kesehariannya. Oleh karena itu, guru tidak boleh mengajar berdasarkan metode yang biasa ia lakukan, tetapi guru harus memperhatikan semua aspek yang terlibat secara langsung atau tak langsung sehingga siswa dapat dibelajarkan secara aktif. Hal ini sesuai dengan pendapat Suherman dkk (2001:60) yang menyatakan bahwa guru hendaknya memilih dan menggunakan strategi, pendekatan, metode dan tehnik yang banyak melibatkan siswa aktif dalam belajar, baik secara mental, fisik maupun sosial.

Yang harus diingat guru dalam memilih metoda pembelajaran, bahwa setiap metode pembelajaran satu sama lain memiliki keunggulan dan kelemahannya masingmasing. Dengan demikian saat pelaksanaanya harus disesuaikan dengan situasi dan kondisi di mana kegiatan pembelajaran akan berlangsung.

\section{Metode Pembelajaran Discovery}

Metode pembelajaran discovery merupakan salah satu metode pengajaran yang progresif serta menitik beratkan kepada aktivitas siswa dalam proses belajar. Secara tegas Amin (1988: 97) mengemukakan bahwa suatu kegiatan "discovery atau penemuan" ialah suatu kegiatan atau pembelajaran yang dirancang sedemikian rupa sehingga siswa dapat menemukan konsep-konsep dan prinsip-prinsip melalui proses mentalnya sendiri. Dalam hal ini penemuan terjadi apabila siswa dalam proses mentalnya seperti mengamati, menggolongkan, membuat dugaan, mengukur, 
menjelaskan, menarik kesimpulan dan sebagainya untuk menemukan beberapa konsep atau prinsip.

Sementara Suryosubroto (2002: 191) mengemukakan bahwa salah satu metode mengajar yang akhir-akhir ini banyak digunakan di sekolah-sekolah yang sudah maju adalah metode discovery. Hal ini disebabkan karena metode ini:

a. Merupakan suatu cara untuk mengembangkan cara belajar siswa aktif;

b. Dengan menemukan sendiri, menyelidiki sendiri, maka hasil yang diperoleh akan setia dan tahan lama dalam ingatan, tak mudah dilupakan anak;

c. Pengertian yang ditemukan sendiri merupakan pengertian yang betul-betul dikuasai dan mudah digunakan atau ditransfer dalam situasi lain;

d. Dengan menggunakan strategi discovery anak belajar menguasai salah satu metode ilmiah yang akan dapat dikembangkan sendiri;

e. Dengan metode ini juga, anak belajar berpikir analisis dan mencoba memecahkan problema yang dihadapi sendiri, kebiasaan ini akan ditransfer dalam kehidupan bermasyarakat.

Adapun langkah-langkah menurut Scuhman dalam Suryosubroto (2002:199) adalah:

a. Identifikasi kebutuhan siswa;

b. Seleksi pendahuluan terhadap prinsip-prinsip, pengertian, konsep dan analogi yang akan dipelajari;

c. Seleksi bahan, dan problema serta tugas-tugas;

d. Membantu memperjelas problema yang akan dipelajari dan peranan masingmasing siswa;

e. Mempersiapkan setting kelas dan alat-alat yang diperlukan;

f. Mencek pemahaman siswa terhadap masalah yang akan dipecahkan dan tugastugas siswa;

g. Memberi kesempatan kepada siswa untuk melakukan penemuan;

h. Membantu siswa dengan informasi, data, jika diperlukan oleh siswa;

i. Memimpin analisis sendiri dengan pertanyaan yang mengarahkan dan mengidentifikasi proses;

j. Merangsang terjadinya interaksi antar siswa dengan siswa;

k. Memuji dan membesarkan siswa yang bergiat dalam proses penemuan;

1. Membantu siswa merumuskan prinsip-prinsip dan analogi atas hasil penemuannya.

Adapun pembelajaran dengan metode discovery yang dimaksud dalam penelitian ini adalah bentuk pembelajaran dimana siswa dengan bantuan guru menemukan kembali konsep, teorema, rumus, aturan dan sejenisnya. Dalam hal ini, guru hanya bertindak sebagai pengarah dan pembimbing saja. 


\section{Metode Pembelajaran Ekspositori}

Metode ekpositori adalah cara penyampaian pelajaran dengan adanya masukanmasukan dari guru, siswa atau lingkungan sekalipun berdasarkan pengalamanpengalaman atau pembuktian. Pengajaran ekspositori tidak terlepas dari metode ceramah, karena sifatnya memberikan informasi, pengajaran berpusatkan pada guru walaupun tidak sebesar metode ceramah. Pada pengajaran ini guru hanya memberikan informasi hanya pada saat-saat atau bagian-bagian yang diperlukan, misalnya pada permulaan pengajaran, pada pengajaran topik yang baru, pada waktu memberikan contoh-contoh soal dan lain sebagainya. Hal ini sesuai dengan pendapat Sudjana (1989), bahwa pada metode ekspositori dominasi guru sangat berkurang, karena tidak terus berbicara saja, ia berbicara pada awal pelajaran, menerangkan materi dan contoh-contoh soal pada waktu-waktu yang diperlukan saja.

Berkenaan dengan metoda ekspositori Suherman dkk (2001:171) menyatakan bahwa, "Kalau materi yang disajikan kepada murid lengkap sampai bentuk akhir yang berupa rumus atau pola bilangan, maka cara belajar murid dikatakan belaja[r menerima". Menurut Rudy (2006: 26) pada metode ekspositori, setelah guru memberikan informasi, guru mulai menerangkan konsep, mendemontrasikan ketrampilannya mengenai dalil-dalil tentang konsep itu, maka siswa dapat bertanya, guru memeriksa apakah siswa sudah memahami materi yang diajarkannya atau belum. Dengan memberikan beberapa contoh-contoh soal aplikasi konsep yang harus dikerjakan siswa, selanjutnya guru dapat meminta salah seorang siswa untuk menyelesaikan soal tersebut, baik dibukunya maupun dipapan tulis. Dengan demikian siswa mungkin ada yang bekerja secara individual tapi tak menutup kemungkinan siswa akan bekerja sama dengan teman-teman yang dekat dengan tempat duduknya, dan tentunya ada semacam tanya jawab dalam proses tersebut, baik antara siswa dengan siswa maupun antara guru-siswa ataupun siswa-guru. Kemudian, sebagai kegiatan terakhir siswa dapat mencatat materi yang telah diterangkan yang mungkin dilengkapi dengan soal-soal tugas dikerjakan di rumah, dan pada pengajaran selanjutnya guru dapat bertanya secara random kepada siswa mengenai hasil pekerjaan rumahnya sebelum kegiatan belajar mengajar selanjutnya dimulai.

\section{Klasifikasi Kemampuan Siswa}

Bila kita berhadapan dengan sejumlah siswa yang tidak khusus dipilih kecerdasannya, maka di antara mereka itu terdapat anak-anak yang berkemampuan tinggi, sedang dan lemah. Ruseffendi (Herdian, 2010) mengatakan bahwa dari sekelompok anak yang tidak dipilih secara khusus terdapat sejumlah anak berbakat hebat yang berada diatas siswa berkemampuan sedang, yang jumlahnya sama dengan anak-anak yang berkemampuan rendah.

Pada Penelitian ini mengklasifikasi kemampuan awal siswa menjadi tiga kelompok, yaitu kelompok tinggi, sedang dan rendah. Proses penentuan kelompok tinggi, 
kelompok sedang dan kelompok rendah ini adalah dengan cara mengurutkan skor hasil belajar matematika sebelumnya (ulangan harian dan ujian tengah semester), serta pengklasifikasian yang dilakukan oleh guru kelas. Hal ini sejalan dengan temuan Begle (Darhim, 2004) melalui penelitiannya bahwa salah satu prediktor terbaik untuk hasil belajar matematika adalah hasil belajar matematika sebelumnya. Lebih lanjut dikatakan bahwa peran variabel kognitif lainnya ternyata tidak sebesar variabel hasil belajar sebelumnya. pengelompokkan siswa didasarkan pada kemampuan awal matematika siswa. Proses penentuan dengan cara mengurutkan skor hasil belajar matematika sebelumnya (ulangan harian dan ujian tengah semester), serta pengklasifikasian yang dilakukan oleh guru kelas. Pengelompokan siswa menjadi tiga kelompok kategori, yaitu kelompok tinggi, sedang, dan rendah dengan perbandingan 30\%, 40\% dan 30\% (Dahlan, 2004).

\section{METODOLOGI PENELITIAN}

Penelitian ini menggunakan metode eksperimen, yang menerapkan metode discovery. Disain penelitian berbentuk Pre-test Post-test Control Group Design. Langkah-langkah yang dilakukan dalam penelitian ini adalah:

a. Sampel dalam penelitian ini dikelompokkan dalam 2 kelas yaitu kelas pertama yang terpilih dijadikan sebagai kelas eksperimen. Sedangkan kelas kedua terpilih dijadikan sebagai kelas kontrol yang dipilih secara acak.

b. Untuk menghindari exstranous variabel , maka variabel-variabel yang diperkirakan membuat penelitian ini bias perlu dinetralkan dengan langkahlangkah sebagai berikut:

1) Kemampuan awal siswa

Kedua kelas adalah kelas yang memiliki kemampuan awal yang sama data dari guru berupa nilai harian siswa dan nilai raport,

2) Lama penyampaian materi

Dalam penelitian ini lama penyampaian materi untuk masing-masing kelas sebanyak 8 kali pertemuan (18 jam pelajaran, 1 jam pelajaran sama dengan 40 menit), ditambah dengan $4 \times 40$ menit untuk postes setelah perlakuan diberikan

3) Buku ajar

Kedua kelompok diberikan bahan ajar yang sama dari buku pegangan yang sama pula.

Dengan demikian rancangan atau disain penelitiannya menggunakan Nonrandomized Control Group Pretest-Posttest Design dapat digambarkan sebagai berikut: 
Tabel 4.1 Desain Penelitian

\begin{tabular}{|l|l|l|l|}
\hline $\begin{array}{l}\text { Treatment } \\
\text { Group }\end{array}$ & $\mathrm{O}$ & $\mathrm{X}$ & $\mathrm{O}$ \\
\hline Control Group & $\mathrm{O}$ & & $\mathrm{O}$ \\
\hline
\end{tabular}

Dimana:

$O$ : Pretest, post test tentang kemampuan analogi dan analogi matematis

$X$ : Perlakuan dengan metode discovery

Penelitian dilakukan pada siswa SMK Al-Ikhsan Pamarican Kabupaten Ciamis Jawa Barat. Populasi target dalam penelitian ini adalah seluruh siswa SMK Al-Ikhsan Pamarican Kabupaten Ciamis Jawa Barat, dengan populasi terjangkau siswa SMK Al-Ikhsan Pamarican Kabupaten Ciamis Jawa Barat.

Sampel penelitian ini terdiri dari 2 kelas, yaitu kelas eksperimen dan kelas kontrol dipilih secara diundi dari 8 kelas ada. Penentuan sampel dilakukan dengan menggunakan teknik "Cluster Random Sampling", karena pengambilan anggota sampel dari populasi dilakukan secara acak tanpa memperhatikan strata yang ada dalam populasi (Sugiyono, 2007: 120).

Untuk memperoleh data dalam penelitian ini, digunakan tiga macam instrument, yang terdiri dari soal tes matematika, format observasi selama pembelajaran matematika, dan menggunakan skala sikap mengenai pendapat siswa terhadap metode discovery.

\section{Tes kemampuan analogi matematis}

Tes yang digunakan adalah tes kemampuan analogi matematis yang terdiri dari tes awal (pretest) dan tes akhir (posttest). Tes yang diberikan pada setiap kelas eksperimen dan kelas kontrol baik soal-soal untuk pretest maupun posttest ekuivalen/ relatif sama. Tes awal dilakukan untuk mengetahui kemampuan awal siswa pada kelas eksperimen maupun kelas kontrol dan digunakan sebagai tolak ukur peningkatan prestasi belajar sebelum mendapatkan pembelajaran dengan metode yang akan diterapkan, sedangkan tes akhir dilakukan untuk mengetahui perolehan hasil belajar dan ada tidaknya pengauh yang signifikan setelah mendapatkan pembelajaran dengan metode pembelajaran yang akan diterapkan.

Untuk memberikan penilaian yang objektif, kriteria pemberian skor untuk soal tes kemampuan analogi matematis berpedoman pada rubrik penskoran kemampuan analogi matematis dengan mengadopsi kriteria penilaian penalaran matematis dari holistic scoring rubrics (Cai, Lane dan Jakabcsin, 1996). Hal ini dikarenakan kemampuan analogi matematis merupakan bagian dari penalaran. 
Tabel 4.2

Kriteria Penilaian Kemampuan Analogi Matematis

\begin{tabular}{|c|l|}
\hline Skor & \multicolumn{1}{|c|}{ Kriteria } \\
\hline 4 & $\begin{array}{l}\text { Dapat menjawab semua aspek pertanyan tentang analogi dan dijawab } \\
\text { dengan benar dan jelas atau lengkap }\end{array}$ \\
\hline 3 & $\begin{array}{l}\text { Dapat menjawab hampir semua aspek pertanyaan tentang analogi dan } \\
\text { dijawab dengan benar } \\
\text { dijawab dengan benar }\end{array}$ \\
\hline 1 & $\begin{array}{l}\text { Menjawab tidak sesuai atas aspek pertanyaan tentang analogi atau menarik } \\
\text { kesimpulan salah }\end{array}$ \\
\hline 0 & Tidak ada jawaban \\
\hline
\end{tabular}

Instrumen penelitian perlu dilakukan uji coba terlebih dahulu. Uji coba dilakukan pada siswa yang telah mendapatkan materi yang akan disampaikan. Uji coba dilakukan untuk mengetahui tingkat validitas, reliabilitas, tingkat kesukaran, dan daya pembeda instrumen tersebut.

Analisis data yang digunakan, yaitu data kuantitatif berupa hasil tes kemampuan analogi matematis siswa, sedangkan data kualitatif berupa: hasil observasi, skala sikap siswa terhadap pembelajaran pemebelajaran dengan metode discovery.

Teknik analisis data yang dilakukan adalah analisis perbedaan dengan menggunakan rumus uji-t. Untuk menguji hipotesis, dilakukan analisis menggunakan rumus statistik untuk menguji kesamaan dua rata-rata. Sebelumnya harus ditentukan dahulu rata-rata skor dan simpangan bakunya. Untuk menentukan uji statistik yang akan digunakan, terlebih dahulu diuji normalitas data dan homogenitas varians. Hipotesis penelitian yang diajukan dalam penelitian ini sebagai berikut:

a. Peningkatan kemampuan analogi matematis siswa yang memperoleh pemebelajaran dengan metode discovery lebih baik dibandingkan dengan siswa yang memperoleh pembelajaran matematika dengan metode ekspositori;

b. Terdapat kaitan yang signifikan antara analogi matematis siswa.

Metode statistik parametrik, uji perbedan dua sampel dilakukan menggunakan uji-t. Hanya saja uji-t mensyaratkan data bertipe interval atau rasio, serta data mengikuti distribusi normal atau dianggap normal. Jika salah satu syarat tidak terpenuhi, maka uji-t harus diganti dengan uji statistik non parametrik yang khusus digunakan untuk dua sampel bebas. Salah satu alat uji dua sampel bebas yaitu uji Mann-Whitney (Santoso, 2005).

Data kemampuan analogi dan generalisasi matematika siswa yang didapat dalam penelitian ini selanjutnya dianalisis dengan uji-t, uji ini dilakukan untuk mengetahui dan memeriksa efektifitas perlakuan. Sedangkan data sikap siswa terhadap 
matematika pada penelitian ini dianalisis dengan uji non parametrik, hal ini dikarenakan data sikap siswa terhadap matematika pada penelitian ini bertipe ordinal. Uji non parametrik yang digunakan adalah uji Mann-Whitney. Uji-t dan uji Mann-Whitney yang digunakan adalah uji satu pihak pada taraf signifikansi $\alpha=$ 0,05 menggunakan program SPSS versi 16.0.

Hipotesis yang diajukan adalah:

$H_{0}: \mu_{x}^{2}=\mu_{y}^{2}$

$H_{1}: \mu_{x}^{2}>\mu_{y}^{2}$

\section{Keterangan:}

$\mu_{x}^{2} \quad$ : rerata skor siswa kelas eksperimen

$\mu_{y}{ }^{2}$ : rerata skor siswa kelas kontrol

$H_{0} \quad$ : rerata skor siswa kelas eksperimen tidak lebih baik daripada kelas kontrol

$H_{l} \quad$ : rerata skor siswa kelas eksperimen lebih baik daripada kelas kontrol

Kriteria Pengujian:

Tolak $H_{0}$ jika p-value (Sig.) $<\alpha=0,05$, sedangkan untuk kondisi lainnya $H_{0}$ diterima.

\section{HASIL PENELITIAN}

Penelitian ini terdiri dari tiga variabel, yaitu variabel hasil belajar siswa (Y) sebagai variabel terikat, variabel kemampuan mengelola stres belajar $\left(\mathrm{X}_{1}\right)$ dan motivasi berprestasi siswa $\left(\mathrm{X}_{2}\right)$ sebagai variabel bebas. Deskripsi hasil penelitian disajikan berupa variabilitas dari ketiga variabel penelitian ini yang mencakup skor tertinggi, skor terendah, simpangan baku, modus, median, dan sebaran data, sebagai dasar untuk pembahasan selanjutnya.

\section{Pengelolaan Data Tes Awal}

Pengolahan data tes awal kelompok eksperimen menggunakan data yang terdapat pada Lampiran, untuk mengetahui deskripsi data tes awal kelompok eksperimen dan deskripsi data tes awal kelompok kontrol disajikan pada Tabel 5.1 berikut:

Tabel 5.1

Statistika Diskriptif Skor Kemampuan Analogi Matematis

\begin{tabular}{|l|r|r|r|r|r|}
\hline & N & Minimum & Maximum & Mean & Std. Deviation \\
\hline Pretes_Analogi_Eksperimen & 36 & 2.00 & 15.00 & 8.2222 & 3.67315 \\
Pretes_Analogi_Kontrol & 36 & 1.00 & 14.00 & 8.2500 & 3.21047 \\
Valid N (listwise) & 36 & & & & \\
\hline
\end{tabular}


Berdasarkan Tabel diatas memperlihatkan bahwa rataan skor kemampuan analogi matematis siswa kelas eksperimen sebelum pembelajaran lebih kecil dibandingkan dengan rataan siswa kelas kontrol, yaitu rataan kelas eksperimen 8,22 dan rataan kelas kontrol adalah 8,25. Dari rataan kedua kelompok tersebut berbedaanya hanya 0,03 hal ini menunjukan bahwa perbedaan yang sangat kecil. Dilihat dari besarnya standar deviasi setelah pembelajaran, penyebaran kemampuan analogi matematis kelas eksperimen kurang menyebar dibandingkan kelas kontrol. Hal itu dapat dilihat bahwa standar deviasi kelas eksperimen lebih rendah daripada standar deviasi kelas kontrol.

Untuk mengetahui apakah terdapat kesamaan kemampuan matematika awal antara siswa yang ada pada kelompok eksperimen dengan kemampuan matematika awal siswa yang ada pada kelompok kontrol, maka kita gunakan uji kesamaan dua ratarata.

\section{a. Menguji Normalitas}

Pengujian normalitas data kemampuan analogi dan generalisasi matematis siswa secara dilakukan dengan menggunakan uji Shapiro-Wilk, dengan menggunakan SPSS 16 for windows. Hasil perhitungan uji normalitas pretes kemampuan analogi matematis dapat dilihat dalam Tabel 5.2 berikut:

Tabel 5.2

Uji Normalitas Skor Pretes Kemampuan Analogi Matematis Siswa

\begin{tabular}{|ll|r|r|r|}
\hline \multirow{2}{*}{} & & \multicolumn{3}{|c|}{ Shapiro-Wilk } \\
\cline { 2 - 5 } & Analogi & Statistik & \multicolumn{1}{c|}{$\mathrm{dk}$} & p-value \\
\hline Pretes & Eksperimen & .945 & 36 & .071 \\
& Kontrol & .953 & 36 & .128 \\
\hline
\end{tabular}

Dari Tabel 5.2 diperoleh $p$-value (Asymp Sig) kelas eksperimen adalah 0,071>0,05 $=\alpha$, dan p-value (Asymp Sig) kelas kontrol adalah 0,128>0,05 $=\alpha$, maka $\mathrm{H}_{0}$ diterima. Sehingga dapat disimpulkan bahwa kemampuan analogi matematis siswa kelas eksperimen dan siswa kelas kontrol berdistribusi normal pada taraf signifikansi $\alpha=0,05$.

\section{b. Menguji Homogenitas}

Pengujian homogenitas data kemampuan analogi matematis siswa secara keseluruhan dilakukan dengan menggunakan uji Levene. Hasil perhitungannya dapat dilihat dalam Tabel 5.3 berikut: 
Tabel 5.3

Uji Homogenitas Variasnsi Skor Pretes Kemampuan Analogi Matematis Siswa

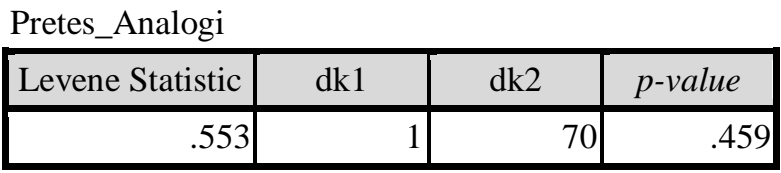

Dari Tabel 5.3 untuk menguji homogenitas varians skor pretes terlihat nilai Lavene Statistic (F) adalah sebesar 0,553 dengan nilai signifikansi sebesar 0,459. Nilai signifikansi tersebut lebih dari taraf signifikansi $\alpha=0,05$ sehingga dapat disimpulkan bahwa $\mathrm{H}_{0}$ yang menyatakan veriansi populasi kedua kelompok data adalah sama diterima. Artinya, kedua kelompok data skor pretes kemampuan analogi matematis siswa memiliki varians yang homogen.

\section{c. Menguji Kesamaan Dua Rata-rata Kemampuan Analogi Matematis Awal Siswa}

Uji ini digunakan untuk menentukan apakah siswa yang ada pada kelompok eksperimen dan siswa yang ada pada kelompok kontrol memiliki kemampuan analogi matematis awal yang sama.

Berdasarkan perhitungan sebelumnya, ternyata data tes awal kelompok eksperimen dan data kelompok kontrol berdistribusi normal dan homogen, maka pengujian kesamaan kemampuan awal siswa digunakan uji-t.

Adapun pasangan hipotesis yang akan diuji pada pengujian homogenitas adalah sebagai berikut:

$\mathrm{H}_{0}$ : tidak terdapat perbedaan rata-rata hasil tes awal antara kelompok kelompok eksperimen dengan kelompok kontrol

$\mathrm{H}_{1}$ : terdapat perbedaan rata-rata hasil tes awal antara kelompok eksperimen dengan kelompok kontrol

Kriteria pengujiannya adalah tolak $\mathrm{H} 0$ jika $t_{\text {tabel }}<t_{\text {hitung }}$ dan terima H0 untuk kondisi lainnya. Kriteria pengujian dengan menggunakan SPSS adalah jika sig $>\alpha$, maka H0 diterima dan jika sig < $\alpha$, maka $\mathrm{H} 0$ ditolak.

Karena pernyataan normalitas dan homogenitas telah dipenuhi, maka untuk menetahui kesamaan rataan pretes kemampuan analogi dan generalisasi metematis siswa yang memperoleh pembelajaran dengan metode discovery dan siswa yang emperoleh pembelajaran dengan metode ekspositori dihitung dengan uji kesamaan rataan skor pretes menggunkan Uji-t. Berikut pada Tabel 5.4 disjikan hasil uji kesamaan rataan kemampuan analogi matematis siswa. 
Tabel. 5.4

Uji Kesamaan Rataan Pretes Kemampuan Analogi Matematis Siswa

\begin{tabular}{|ll|r|r|r|}
\hline & & & \multicolumn{2}{c|}{$\begin{array}{c}\text { p-value } \\
\text { (2-tailed) }\end{array}$} \\
\hline Pretes & Enalogi & $\mathrm{t}$ & $\mathrm{dk}$ & .973 \\
& Equal variances assumed & -.034 & 70 & .973 \\
\hline
\end{tabular}

Berdasarkan Tabel 5.4 diatas dapat dilihat bahwa signifikansi sebesar 0,973 > dari $\alpha$ $=0,05$. Sehingga $\mathrm{H}_{0}$ diterima, yang artinya kemampuan awal analogi matematis siswa yang memperoleh pembelajaran dengan metode discovery sama dengan rataan kemampuan awal analogi matematis siswa yang memperoleh pembelajaran dengan metode ekspositori.

\section{Pengolahan Data Gain Ternoralisasi Kemampuan Analogi Matematis}

Untuk menguji peningkatan kemampuan penalaran matematik siswa, maka kita tentukan terlebih dahulu nilai gain dari masing-masing nilai siswa. Untuk menentukan gain masing-masing siswa, digunakan rumus berikut:

$$
\begin{aligned}
& \mathrm{g}=\frac{\text { post testscore }- \text { pretest score }}{\text { Maximum possiblescore - pretest score }} \\
& \text { (Meltzer, 2002, h.1260) }
\end{aligned}
$$

Dengan menggunakan bantuan program SPSS 16 for Windows, diperoleh statistik diskriptif data dan gain ternormalisasi kemampuan analogi matematis sebagai berikut:

Tabel 5.5

Statistika Diskriptif Gain Ternormalisasi Kemampuan Analogi Matematis

\begin{tabular}{|l|r|r|r|r|r|}
\hline & N & Minimum & Maximum & Mean & Std. Deviation \\
\hline Pretes_Analogi_Eksperimen & 36 & 2.00 & 15.00 & 8.2222 & 3.67315 \\
Postes_Analogi_Eksperimen & 36 & 8.00 & 19.00 & 15.2778 & 3.36886 \\
Gain_Analogi_Eksperimen & 36 & .20 & .89 & .6308 & .19009 \\
Pretes_Analogi_Kontrol & 36 & 1.00 & 14.00 & 8.2500 & 3.21047 \\
Postes_Analogi_Kontrol & 36 & 6.00 & 19.00 & 13.9167 & 2.94109 \\
Gain_Analogi_Kontrol & 36 & .18 & .88 & .4925 & .16712 \\
Valid N (listwise) & 36 & & & \\
\hline
\end{tabular}

Berdasarkan tabel diatas memperlihatkan bahwa rataan skor kemampuan analogi matematis siswa kelas eksperimen sebelum pembelajaran lebih kecil dibandingkan 
dengan rataan siswa kelas kontrol, yaitu rataan kelas eksperimen 8,22 dan rataan kelas kontrol adalah 8,25. Dari rataan kedua kelompok tersebut berbedaanya hanya 0,03 hal ini menunjukan bahwa perbedaan yang sangat kecil. Sedangkan stelah pembelajaran dilakukan rataan skor kemampuan analogi matematis kelas eksperimen adalah 15,28 dengan standar deviasi 3,39. Sedangkan pada kelas kontrol, setelah pembelajran rataanya adalah 13,92 dengan standar deviasi 2,94. Dilihat dari besarnya standar deviasi setelah pembelajaran, penyebaran kemampuan analogi matematis kelas eksperimen kurang menyebar dibandingkan kelas kontrol. Hal itu dapat dilihat bahwa standar deviasi kelas eksperimen lebih rendah daripada standar deviasi kelas kontrol.

\section{a. Menguji Normalitas}

Pengujian normalitas data gain ternormalisasi kemampuan analogi dan generalisasi matematis siswa secara dilakukan dengan menggunakan uji Shapiro-Wilk, dengan menggunakan SPSS 16 for windows. Hasil perhitungan uji normalitas pretes kemampuan analogi matematis dapat dilihat dalam Tabel 5.6 berikut:

Tabel 5.6

Uji Normalitas Gain Ternormalisasi Kemampuan Analogi Matematis Siswa

\begin{tabular}{|ll|r|r|r|}
\hline \multirow{2}{*}{} & \multirow{2}{*}{ Analogi } & \multicolumn{3}{|c|}{ Shapiro-Wilk } \\
\cline { 2 - 5 } Pretes & Statistik & \multicolumn{1}{c|}{$\mathrm{dk}$} & p-value \\
& Eksperimen & .945 & 36 & .071 \\
& Kontrol & .953 & 36 & .128 \\
\hline
\end{tabular}

Dari Tabel 5.6 diperoleh $p$-value (Asymp Sig) kelas eksperimen adalah 0,071>0,05 $=\alpha$, dan $p$-value (Asymp Sig) kelas kontrol adalah 0,128>0,05 $=\alpha$, maka $\mathrm{H}_{0}$ diterima. Sehingga dapat disimpulkan bahwa gain ternormalisasi kemampuan analogi matematis siswa kelas eksperimen dan siswa kelas kontrol berdistribusi normal pada taraf signifikansi $\alpha=0,05$.

\section{b. Menguji Homogenitas}

Pengujian homogenitas data gain ternormalisasi kemampuan analogi matematis siswa secara keseluruhan dilakukan dengan menggunakan uji Levene. Hasil perhitungannya dapat dilihat dalam Tabel 5.7 berikut:

Tabel 5.7

Uji Homogenitas Variansi Gain Ternormalisasi Kemampuan Analogi Matematis Siswa

\begin{tabular}{|c|c|c|c|}
\hline Levene Statistic & $\mathrm{dk} 1$ & $\mathrm{dk} 2$ & p-value \\
\hline .553 & 1 & 70 & .459 \\
\hline
\end{tabular}


Dari tabel 4.3 untuk menguji homogenitas varians skor pretes terlihat nilai Lavene Statistic (F) adalah sebesar 0,553 dengan nilai signifikansi sebesar 0,459. Nilai signifikansi tersebut lebih dari taraf signifikansi $\alpha=0,05$ sehingga dapat disimpulkan bahwa $\mathrm{H}_{0}$ yang menyatakan veriansi populasi kedua kelompok data adalah sama diterima. Artinya, kedua kelompok data gain ternormalisasi kemampuan analogi matematis siswa memiliki varians yang homogen.

\section{c. Menguji Hipotesis Kemampuan Analogi Matematis}

Uji ini digunakan untuk menentukan apakah kemampuan analogi siswa yang ada pada kelompok eksperimen lebih baik daripada kemampuan analogi matematis siswa kelas eksperimen.

Berdasarkan perhitungan sebelumnya, ternyata data tes awal kelompok eksperimen dan data kelompok kontrol berdistribusi normal dan homogen, maka pengujian kesamaan kemampuan awal siswa digunakan uji-t.

Adapun pasangan hipotesis yang akan diuji pada pengujian homogenitas adalah sebagai berikut:

$\mathrm{H}_{0}$ : tidak terdapat perbedaan rata-rata hasil tes awal antara kelompok kelompok eksperimen dengan kelompok kontrol

$\mathrm{H}_{1}$ : terdapat perbedaan rata-rata hasil tes awal antara kelompok eksperimen dengan kelompok kontrol

Kriteria pengujiannya adalah tolak $\mathrm{H}_{0}$ jika $t_{\text {tabel }}<t_{\text {hitung }}$ dan terima $\mathrm{H}_{0}$ untuk kondisi lainnya. Kriteria pengujian dengan menggunakan SPSS adalah jika sig $>\alpha$, maka $\mathrm{H}_{0}$ diterima dan jika sig < $\alpha$, maka $\mathrm{H}_{0}$ ditolak.

Karena pernyataan normalitas dan homogenitas telah dipenuhi, maka untuk menetahui kesamaan rataan pretes kemampuan analogi dan generalisasi metematis siswa yang memperoleh pembelajaran dengan metode discovery dan siswa yang emperoleh pembelajaran dengan metode ekspositori dihitung dengan uji kesamaan rataan skor pretes menggunkan Uji-t. Berikut pada Tabel 5.8 disjikan hasil uji kesamaan rataan kemampuan analogi mateatis siswa.

Tabel. 5.8

Uji Perbedaan Rataan Gain Kemampuan Analogi Matematis Siswa

\begin{tabular}{|cl|r|r|r|}
\hline & & & \multicolumn{1}{c|}{$\begin{array}{c}p \text {-value } \\
\text { (2-tailed) }\end{array}$} \\
\hline Pretes $\quad$ Enalogi & $\mathrm{t}$ & \multicolumn{1}{c|}{$\mathrm{dk}$} & .002 \\
& Equal variances assumed & 3.279 & 70 & .002 \\
\hline
\end{tabular}


Berdasarkan Tabel 5.8 diatas dapat dilihat bahwa signifikansi sebesar $0,002<$ dari $\alpha$ $=0,05$. Sehingga $\mathrm{H}_{1}$ diterima, yang artinya kemampuan analogi matematis siswa yang memperoleh pembelajaran dengan metode discovery lebih baik daripada kemampuan analogi matematis siswa yang diajarkan dengan metode ekspositori.

\section{Pembahasan}

Berdasarkan data penelitian, diketahui bahwa skor rerata kemampuan analogi matematis siswa kelas eksperimen dan siswa kelas kontrol secara berturut-turut adalah 15,00 dan 14,00 . Secara kasat mata dapat diketahui bahwa terdapat perbedaan antara skor rerata kemampuan analogi siswa kelas eksperimen dan siswa kelas kontrol. Namun apakah perbedaan tersebut signifikan? Untuk itu dilakukan uji perbedaan dua rerata menggunakan uji-t. Hasil pengujian menunjukkan bahwa terdapat perbedaan yang signifikan antara rerata skor siswa kelas eksperimen dan siswa kelas kontrol pada taraf signifikansi $\alpha=0,05$. Sehingga dapat disimpulkan bahwa kemampuan analogi matematis siswa yang belajar menggunakan metode discovery lebih baik dibandingkan dengan siswa yang belajar menggunakan metode ekspositori.

Selanjutnya dilakukan uji perbedaan dua rerata menggunakan uji-t untuk mengetahui apakah terdapat perbedaan yang signifikan skor rerata kedua kelas. Hasil analisis data menunjukkan bahwa terdapat perbedaan yang signifikan antara rerata skor siswa pandai kelas eksperimen dan siswa pandai kelas kontrol pada taraf signifikansi $\alpha=0,05$. Sehingga dapat disimpulkan bahwa kemampuan analogi matematis siswa pandai yang belajar menggunakan metode discovery lebih baik dibandingkan dengan siswa pandai yang belajar menggunakan metode ekspositori.

Lebih baiknya kemampuan analogi dan generalisasi matematis siswa yang belajar menggunakan metode discovery dibandingkan siswa yang belajar menggunakan metode ekspositori disebabkan karena metode discovery mendorong perkembangan aktual dan perkembangan potensial siswa. Melalui pertayaan-pertanyan yang dimuat dalam lembar kerja siswa (LKS), akan mendorong perkembangan aktual siswa. Sedangkan melalui interaksi antar siswa mendorong perkembangan potensial siswa.

Selain itu, siswa yang belajar menggunakan metode discovery dituntut melakukan pengamatan, mengklasifikasikan, membuat analogi, menganalisis, dan membuat kesimpulan (generalisasi) untuk menemukan konsep, prosedur dan prinsip matematika secara individual maupun kelompok. Sehingga melalui aktivitas mental seperti itu, kemampuan analogi siswa akan berkembang dengan baik.

Terjadinya aktivitas mental dalam menemukan konsep, prosedur dan prinsip matematika sangat bergantung pada pertanyaan-pertanyaan yang disajikan dalam lembar kerja siswa (LKS). Pertanyaan-pertanyan yang diajukan harus mendorong siswa melakukan proses analisis, menemukan analogi, dan melakukan generalisasi. 
Dalam mengkontruksi konsep matematika baik secara individu maupun kelompok melalui proses analisis, menemukan analogi, dan melakukan generalisasi, siswa sebaiknya mendapat bantuan dari guru. Bantuan yang diberikan dapat berbentuk pertanyaan-pertanyaan yang lebih sederhana dan lebih mengarahkan siswa untuk mengkontruksi suatu konsep matematika. Pembelajaran dengan metode discovery akan efektif bila pertanyaan-pertanyaan dalam lembar kerja siswa (LKS) disajikan dengan tepat sehingga dapat merangsang proses berpikir siswa secara optimal. Ini artinya pertanyaan-pertanyaan dalam lembar kerja siswa (LKS) harus mendorong siswa melakukan proses discovery.

Berhasil atau tidaknya siswa menemukan konsep, prosedur dan pinsip matematika tergantung pula pada bentuk pertanyaan-pertanyaan yang diajukan guru secara lisan pada saat proses pembelajaran. Pertanyaan-pertanyaan yang diajukan harus terjangkau oleh pikiran siswa. Hal tersebut agar tidak membuat siswa gagal dalam menemukan konsep. Hal ini dimaksudkan agar siswa tidak merasa frustasi, yang dapat mengakibatkan mereka kehilangan semangat dan kepercayaan diri dalam menemukan konsep matematika.

Selain beberapa kelebihan yang ditemukan, dalam pembelajaran menggunakan metode discovery ini juga ditemukan beberapa keterbatasan-keterbatasan, yaitu:

a. Penelitian ini hanya dilakukan dalam waktu yang relatif singkat dan sangat terbatas, yaitu kurang lebih hanya 6 pekan, sehingga akan berdampak pada hasil penelitian yang dicapai.

b. Populasi penelitian ini hanya siswa SMK Al-Ikhsan Pamarican Kabupaten Ciamis Jawa Barat dan sampel yang diambil hanya dua kelas sehingga hasil penelitian ini belum tentu sesuai dengan sekolah atau daerah lain yang memiliki karakteristik dan psikologi siswa yang berbeda. Diharapkan kepada peneliti lainnya agar bisa menggunakan populasi yang lebih luas dengan kelas yang dijadikan sampel lebih banyak, dengan tujuan memperkecil kesalahan dan mendapatkan hasil yang lebih akurat.

c. Bahan ajar yang dikembangkan dalam penelitian ini hanya terdiri dari satu pokok bahasan, yaitu bilangan pangkat. Masih terbuka kesempatan bagi peneliti lainnya untuk melakukan eksperimen pada pokok bahasan yang berbeda dan mungkin lebih dari satu pokok bahasan.

\section{SIMPULAN, IMPLIKASI DAN SARAN}

\section{Simpulan}

Berdasarkan data penelitian dan hasil analisis data diperoleh beberapa kesimpulan terkait dengan hipotesis-hipotesis penelitian yaitu Kemampuan analogi matematis siswa yang belajar dengan metode discovery lebih baik daripada siswa yang belajar dengan metode ekspositori. 
Melalui penelitian ini terungkap bahwa ditinjau secara keseluruhan, maupun dilihat dari kemampuan awal, siswa yang belajar dengan metode discovery memiliki skor rerata kemampuan analogi matematis siswa yang lebih baik dibandingkan dengan siswa yang belajar dengan metode ekspositori. Terdapat beberapa dugaan sebagai alasan mengapa siswa yang belajar dengan metode discovery memiliki skor rerata kemampuan analogi matematis siswa yang lebih baik dibandingkan dengan siswa yang belajar dengan metode ekspositori.

Pertama, metode discovery menuntut siswa membuat analogi, dalam menemukan konsep, prosedur dan prinsip matematika secara individual maupun kelompok. Siswa mengaitkan kesamaan (analogi) konsep yang telah mereka dapatkan/ ketahui sebelumnya dengan konsep yang sedang dipelajari guna menemukan konsep baru tentang materi yang sedang dipelajari. Sehingga sejak awal siswa yang belajar dengan metode discovery telah terlatih menggunakan analogi dalam menyelesaikan masalah matematika. Tidak heran jika saat tes akhir siswa yang belajar dengan metode discovery memperoleh skor rerata kemampuan analogi matematis siswa yang lebih baik dibandingkan dengan siswa yang belajar dengan metode ekspositori.

Kedua, metode discovery mendorong perkembangan aktual dan perkembangan potensial siswa. Melalui pertayaan-pertanyan yang dimuat dalam lembar kerja siswa (LKS), akan mendorong perkembangan aktual siswa. Sedangkan melalui interaksi antar siswa mendorong perkembangan potensial siswa.

\section{Saran}

Berdasarkan hasil penelitian yang diperoleh, maka rekomendasi penelitian yang disampaikan, antara lain:

a. Pembelajaran dengan metode discovery lebih tepat digunakan pada siswa dengan kemampuan awal pandai, karena metode menemukan konsep matematika secara individual maupun kelompok memerlukan kemampuan prasyarat yang baik, dan siswa berkemampuan pandai memenuhinya.

b. Sebelum guru menggunakan metode discovery, sebaiknya guru terlebih dahulu mengidentifikasi kemampuan siswanya. Jika kemampuan siswa pada kelas tersebut heterogen, sebaiknya guru mengkombinasikan metode discovery dengan pembelajaran cooperative. Tujuannya agar siswa berkemapuan lemah dapat terbantu oleh rekan kelompoknya yang lebih pandai.

c. Apabila guru matematika SMK akan menggunakan metode discovery dalam proses pembelajaran maka perlu mempertimbangkan antara lain waktu yang tersedia, pemilihan pokok bahasan yang relevan dengan proses penemuan, kesiapan siswa serta pengelolaan kelas.

d. Bagi guru atau peneliti lain yang ingin mengembangkan instrumen kemampuan analogi matematika, sebaiknya instrumen analogi yang dibuat menekankan pada proses menemukan kesamaannya dan tidak memberatkan siswa pada proses menghitung. 
e. Penelitian yang dilakukan ini sifatnya sangat terbatas baik subjek penelitian, dan pokok bahasan. Populasi penelitian ini hanya siswa SMK Al-Ikhsan Pamarican Kabupaten Ciamis Jawa Barat dan sampel yang diambil hanya dua kelas sehingga hasil penelitian ini belum tentu sesuai dengan sekolah atau daerah lain yang memiliki karakteristik dan psikologi siswa yang berbeda. Diharapkan kepada peneliti lainnya agar bisa menggunakan populasi yang lebih luas dengan kelas yang dijadikan sampel lebih banyak, dengan tujuan memperkecil kesalahan dan mendapatkan hasil yang lebih akurat. Bahan ajar yang dikembangkan pun hanya terdiri dari satu pokok bahasan, yaitu lingkaran. Masih terbuka kesempatan bagi peneliti lainnya untuk melakukan eksperimen pada pokok bahasan yang berbeda dan mungkin lebih dari satu pokok bahasan.

f. Dalam upaya implementasi metode discovery di sekolah menengah pertama, direkomendasikan kepada para pengambil kebijakan pendidikan untuk mengadakan perubahan-perubahan terhadap paradigma pembelajaran matematika yang selama ini kurang sesuai dengan kaidah-kaidah metode discovery. Misalnya, tentang pandangan terhadap matematika, siswa dan guru. Dalam pandangan metode discovery, matematika tidak dipandang sebagai suatu ilmu/ bidang kajian yang sudah jadi dan disajikan dalam bentuk akhir, tetapi dipandang sebagai sesuatu yang harus dikontruksi sendiri oleh siswa. Siswa seyogyanya tidak lagi dipandang sebagai pihak yang mempelajari segala sesuatu yang sudah dalam bentuk akhir (jadi), tetapi harus dipandang sebagai pihak yang aktif mengkontruksi konsep dan materi matematika yang ditemukan secara individual maupun kelompok. Perubahan tentang pandangan guru terutama tidak lagi dipandang sebagai pengajar, tetapi lebih sebagai pendamping bagi para siswa.

\section{DAFTAR PUSTAKA}

Alamsyah. (2002). Suatu Pembelajaran untuk Meningkatkan Kemampuan Penalaran Analogi Matematika. Tesis S.Ps. UPI Bandung: Tidak diterbitkan.

Ashar. J. (1998). Peningkatan Guru SMP dalam Mengorganisasi Cooperative Learning pada Pembelajaran Matematika di SMP. FKIP Bengkulu.

Araceli, A.V. dkk. (2006). First PISA 2006 Project for International Assessment of 15-Year-Old Student in Science, Mathematics and Reading. Bilbao: Instituto Vasco de Eduacione e Investigacion Educativa.

Asyhadi, A. (2005). Pengenalan Laboratorium Matematika di Sekolah. IHT Media Bagi Staff LPMP Pengelolaan Laboratorium Matematika Tanggal 5 s.d. 11 September 2005 di PPPG Matematika Yogyakarta.

Arikunto, S (1999). Prosedur Penelitian Suatu Pendekatan Praktek. Edisi Revisi IV. Jakarta : Rineka Cipta. (2002). Dasar-Dasar Evaluasi Pendidikan. Edisi Revisi. Jakarta: Bumi Aksara. 
Bell, F.H.(1987). Teaching and Learning Mathematics (In Secondary Schools). University of Pittsburgh.

Cai, J.L. dkk (1996). Communication in Mathematics K-12 and Beyond. Virginia: NCTM.

Dahlan, J.A. (2004). Meningkatkan Kemampuan Penalaran dan Pemahaman Matematika Siswa Sekolah Menengah Tingkat Pertama (SLTP) Melalui Pendekatan Pembelajaran Open-Ended. Disertasi S.Ps. UPI: Tidak Diterbitkan.

Darhim. (2004). Pengaruh Pembelajaran Matematika Kontekstual terhadap Hasil belajar Matematika Siswa Sekolah Dasar. Disertasi UPI. Bandung : Tidak diterbitkan.

Darsono, M. (2000). Belajar dan Pembelajaran. Semarang: IKIP Semarang Press.

Departemen Pendidikan Nasional. ( 2002). Kurikulum 2004 Standar Kompetensi Mata Pelajaran Matematika, Sekolah Menengah Atas dan Madrasah Aliyah Jakarta : Depdiknas.

(2006). Standar Isi dan Kompetensi Lulusan untuk Satuan Pendidikan Dasar dan Menengah. [online]. Tersedia: groups.yahoo.com/group/dikmenjur/message/4564.

Dimyati dan Mudjiono. (2002). Belajar dan Pembelajaran. Jakarta : Rineka Cipta.

Edward W.M, Bruce M.K. (1993). Statistical Reasoning in Psychology and Education. New York: Lehigh Press.

Fahrurozi. (2011). Penerapan Pembelajaran Berbasis Masalah untuk Meningkatkan Kemampuan Berpikir Kritis dan Matematis Siswa. Jurnal Pendidikan Matematika Edisi khusus Vol. 1.

Fajar, S. (2001). Bagaimana Cara Guru Memanfaatkan Faktor Sikap dalam Pembelajaran. Tersedia di www.fadjarp3g.wordpress.com.

Frederick, H.B. (1978). Teaching and Learning Mathematics ( In Secondary Schools). New York: Brown Company Publishers.

Hake, R.R. (1999). Analizing Changel Gain Scores. [Online]. Tersedia: http://www.physics.indiana.edu/ sdi/AnalyzingChange-Gain.pdf.

Herdian, (2010). Pengaruh Metode Descovery Terhadap Kemampuan Analogi dan Generalisasi Matematis Siswa SMP. Tesis UPI Bandung: Tidak diterbitkan

Jacobs, J. (2004). The Limits of Discovery Learning. [online]. Tersedia di http://www.joannejacobs.com/mtarchives/013751.html. [November 2009]

Kite, C.D. (2005). Discovery Learning, Lesson Planning. [online]. Tersedia: http://www.members.aol.com/kiteCD2/artel-disclearn.html. $\quad[10$ November 2009]

Kusumah, Y.S. (2008). Konsep, Pengembangan dan Implementasi Computer Based Learning dalam Peningkatan Kemampuan High-Order Mathematics Thinking. Makalah disajikan dalam Pengukuhan Guru Besar Matematika FMIPA UPI.

Lisnawaty, S. (1993). Metode Mengajar Matematika. Jakarta: Rineka Cipta.

Muhibbin, S. (2003). Psikologi Belajar. Jakarta: Raja Grafindo Persada.

Mundari. (2010). Logika. Jakarta: Raja Grafindo Persada. 
Kusumah, Y. (1986). Logika Matematika Elementer. Bandung: Tarsito

Natioanl Council of Teachers of Mathematics. (1989). Curriculum and Evaluation Standards for School Mathematics. USA: The Natioanl Council of Teachers of Mathematics, Inc.

Nur, Muhammad. (2004). Pengajaran Berpusat pada Siswa dan Pendekatan Konstruktivisme dalam Pembelajaran. Modul kuliah UNESA: Tidak diterbitkan

Priatna, N. (2003). Kemampuan Penalaran dan Pemahaman Matematika Siswa Kelas 3 SLTP di Kota Bandung. Disertasi S.Ps. UPI Bandung: Tidak diterbitkan.

Rahman, A. (2004). Meningkatkan Kemampuan Pemahaman dan Kemampuan Generalisasi Siswa SMA melalui pembelajaran Berbalik. Tesis S.Ps. UPI Bandung: Tidak diterbitkan.

Robert, A.G, dkk. (2008). TIMSS advanced 2008 Assesment Frame Work. United States of America: The Third Internatioanal Mathematics and Science Study.

Rochaminah, S. (2008). Pengaruh Pembelajaran Penemuan terhadap Kemampuan Berpikir Kritis dan Matematis Mahasiswa Calon Guru. Disertasi S.Ps. UPI Bandung: Tidak diterbitkan.

Roestiyah, N.K. (2001). Strategi Belajar Mengajar. Jakarta: Rineka Cipta.

Ruseffendi, E.T. (1984). Dasar-Dasar Matematika Modern dan Komputer Untuk Guru. Bandung : Tarsito.

(1991). Pengantar Kepada Membantu Guru Mengembangkan Kompetensinya dan Pengajaran Matematika untuk Meningkatkan CBSA. Bandung: Tarsito.

Sagala, S. (2009). Strategi Pembelajaran Berorientasi Standard Proses Pendidikan. Jakarta: Kencana Persada Media Grup.

Saragih, S. (2011). Penerapan Pendekatan Pembelajaran Matematika Realsistik dengan Kelompok Kecil untuk Meningkatkan Kemampuan Keruangan, Berpikir Logis dan Sikap Positip terhadap Siswa SMP. Disertasi S.Ps. UPI Bandung: Tidak diterbitkan.

Sastrosudirjo, S.S. (1988). Hubungan Kemampuan Penalaran dan Prestasi Belajar untuk Siswa SMP. Jurnal Kependidikan no.1 Tahun ke 18. IKIP Yogyakarta.

Soekadijo, G.R. (1999). Logika Dasar Tradisional, Simbolik dan Induktif. Jakarta: Gramedia.

Sudijono, A. (2001). Pengantar Evaluasi Pendidikan. Jakarta : PT. Raja Grafindo Persada.

Sudjana,N. (1980). Dasar-dasar Proses Belajar Mengajar. Bandung : Sinar Baru. . (2005). Metode Statistika. Bandung: Tarsito.

. (1989). Cara Belajar Siswa Aktif dalam Proses Belajar Mengajar.

Bandung: Sinar Baru Algesindo.

Sugiyono. (2008). Metode Penelitian Pendidikan. Bandung : CV. Alfabeta.

Suherman, dkk. (2001). Common TexBook Strategi Pembelajaran Matematika Kontemporer. Bandung: Jurusan Pendidikan Matematika UPI Bandung. 
Suherman, E. dan Sukjaya, Y. (1990). Petunjuk Praktis untuk Melaksanakan Evaluasi Pendidikan Matematika. Bandung.

Sumarmo, U. (1987). Kemampuan Pemahaman dan Penalaran Matematika Siswa Dikaitkan dengan Kemampuan Penalaran Logik Siswa dan Beberapa Unsur Proses Belajar Mengajar. Disertasi S.Ps. UPI Bandung: Tidak diterbitkan. . (2005). Pengembangan Berpikir Matematika Tingkat Tinggi Siswa SLTP dan SMU serta Mahasiswa Strata Satu (S1) Melalui Berbagai Pendekatan Pembelajaran. Laporan Penelitian. SPs. UPI Bandung: Tidak diterbitkan.

Suriadi. (2006). Pembelajaran dengan Pendekatan Discovery yang Menekankan Aspek Analogi Untuk Menigkatkan Pemahaman Matematik dan Kemampuan Berfikir Kritis Siswa SMA. Tesis S.Ps. UPI Bandung: Tidak diterbitkan.

Suriasumantri, J.S. (2005). Filsafat Ilmu Sebuah Pengantar Populer. Jakarta: Pustaka Sinar Harapan.

Suriayadi, D. (2005). Penggunaan Pendekatan Pembelajaran Tidak Langsung dalam Rangka Meningkatkan Kemampuan Berpikir Matematik tingkat Tinggi Siswa SLTP. Disertasi Doktor Pada SPs. UPI: Tidak diterbitkan.

Suryosubroto. (2002), Proses Belajar Mengajar di Sekolah. Jakarta: Rineka Cipta.

Suzana, Y. (2003). Meningkatkan Kemampuan Pemahaman dan Penalaran Matematika Siswa Sekolah Menengah Umum melalui Pembelajaran dengan Pendekatan Kognitif. Tesis UPI Bandung: tidak diterbitkan.

Trisnadi, A. (2006). Meningkatkan Pemahaman dan Generalisasi Matematika Siswa Sekolah Menengah Pertama Melalui Pembelajaran Pertemuan Terbimbing dalam Kelompok. Tesis S.Ps. UPI Bandung: Tidak Diterbitkan.

Turmudi. (2008). Landasan Filsafat dan Teori Pembelajaran Matematika. Leuser Cita Pustaka.

Wahyudin. (1999). Kemampuan Guru Matematika, Calon Guru Matematika, dan Siswa dalam Pelajaran Matematika. Laporan penelitian IKIP Bandung. Bandung: Tidak diterbitkan.

Widiarso, W. (2007). Uji Hipotesis Komparatif. [on line]. tersedia. http://elisa.ugm.ac.id/community/home/show/statistikaptu1003/\#!/section/701 3/1336745918.

Widjajanti, D. (2011). Problem Based Learning dan Contoh Implementasinya. Makalah Universitas Negri Yogyakarta.

Yuliani, A. (2011). Meningkatkan Kemampuan Analogi dan Generalisasi Matematis Siswa SMP dengan Model Pembelajaran Inkuiri Terbimbing. SPs. UPI Bandung: Tidak diterbitkan. 